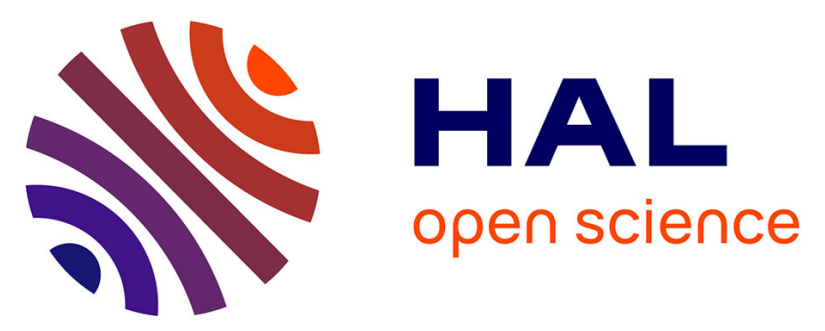

\title{
The presence of putative sulphur-oxidizing bacteria colonizing the periostracal secretion in the endosymbiont-bearing bivalve Loripes lucinalis
}

\author{
M.A. Jonhson, C. Fernandez
}

\section{- To cite this version:}

M.A. Jonhson, C. Fernandez. The presence of putative sulphur-oxidizing bacteria colonizing the periostracal secretion in the endosymbiont-bearing bivalve Loripes lucinalis. Journal of the Marine Biological Association of the UK, 2001, 81, pp.893-894. hal-00019196

\author{
HAL Id: hal-00019196 \\ https://hal.science/hal-00019196
}

Submitted on 27 Feb 2006

HAL is a multi-disciplinary open access archive for the deposit and dissemination of scientific research documents, whether they are published or not. The documents may come from teaching and research institutions in France or abroad, or from public or private research centers.
L'archive ouverte pluridisciplinaire HAL, est destinée au dépôt et à la diffusion de documents scientifiques de niveau recherche, publiés ou non, émanant des établissements d'enseignement et de recherche français ou étrangers, des laboratoires publics ou privés. 


\title{
The presence of putative sulphur-oxidizing bacteria colonizing the periostracal secretion in the endosymbiont-bearing bivalve Loripes lucinalis
}

\author{
M.A. Johnson and C. Fernandez
}

EqEL, UFR Sciences, BP 52, 20250 Corte, France. E-mail: atalarmin@aol.com

\begin{abstract}
Loripes lucinalis, a small bivalve belonging to the Lucinacea superfamily living in reducing coastal sediments, possesses chemoautotrophic sulphur-oxidizing bacteria in its gill. Here, a population of putative sulphur-oxidizing bacteria is described colonizing the bivalve's inner periostracal secretion. The bacteria were particularly abundant in the vicinity of the anterior and posterior inhalant syphons. Most of the bacteria observed were oval to rod-shaped and measured $3.9 \pm 1.2 \mu \mathrm{m}$ on average Histology and negative transmission electron microscopy staining revealed that these bacteria contain refractile spherules similar to those seen in the endocellular gill symbionts of $L$. lucinalis.
\end{abstract}

All symbiotic associations must be able to maintain the animal-bacteria partnership over successive host generations. In terms of transfer mechanisms from one generation to the next, the transmission of endosymbionts in invertebrate microorganism symbioses can involve a transgonadal acquisition, implying that symbionts are acquired by the gametes within the gonad, or a postspawning acquisition, when symbionts are acquired following gamete release to the environment (Le Pennec \& Beninger, 2000). Indications of possible transmission mechanisms in the literature would tend to suggest that these mechanisms are as varied as the host species themselves.

In an effort to increase our understanding of chemoautotrophic symbioses and transmission mechanisms, the occurrence of apparently chemoautotrophic sulphur-oxidizing bacteria colonizing the inner periostracal secretion is herein described in the lucinid Loripes lucinalis. This small bivalve lives in reducing coastal sediments and possesses a gcographical distribution that extends from the Canary Islands to the Isle of Man. The general macro-anatomy of the L. lucinalis gill, composed of bacteriocyte cylinders and channels (Johnson \& Fernandez, 2001), is identical to that described for other lucinid clams (Distel \& Felbeck, 1987; Frenkiel \& Mouza, 1995). The endosymbionts, which are observed within the bacteriocytes of the gill, are chemoautotrophic sulphur-oxidizing bacteria (Diouris et al., 1988; Herry ct al., 1989; Johnson et al., 1994)

Specimens of $L$. lucinalis were collected by digging at low tide in the reducing sediment of the Moulin Blanc beach, Brest Brittany, France). Live clams $(\mathrm{N}=10)$ were transported to the laboratory on ice and fixed (with their shell) in Bouin's solution minimum one week). The samples were then dehydrated in alcohol and embedded in Jung histological resin as per the manufacturer's instructions. Sections $\sim 5 \mu \mathrm{m}$ thick were cut and stained with toluidine blue for light microscopy.

For negative transmission electron microscopy (TEM) staining, the inner shell surface of freshly opened specimens was scraped with a sterile razor blade and the material adhering to the blade was suspended in $0.2 \mu \mathrm{m}$ filtered seawater. One drop of this mixture was placed on a copper filter coated with a carbon and collodiob film. Each filter was rinsed twice with an ammonium acetate buffer $(0.1 \mathrm{M}, \mathrm{pH} 7.2)$ and the excess liquid was removed by blotting after each rinsing event. The filters were then contrasted for one minute with a $1 \%$ aqueous solution of uranyl acetate and observed with a $100 \mathrm{CX}$ JEOL microscope.

For ultrastructural analysis, gill tissue was fixed for $24 \mathrm{~h}$ at $4^{\circ} \mathrm{C}$ in $3 \%$ glutaraldehyde in $0.2 \mathrm{M}$ cacodylate buffer $(\mathrm{pH} 7.5$ ) adjusted with $\mathrm{NaCl}$ to $1300 \mathrm{mOsm}$, post-fixed with $2 \%$ osmium tetroxide in the same buffer for $3 \mathrm{~h}\left(4^{\circ} \mathrm{C}\right)$ and embedded in Spurr resin. Semi-thin sections were cut, stained with toluidine blue and observed under light microscopy. Ultra-thin sections were cut and stained with $7 \%$ uranyl acetate and $0.1 \%$ lead citrate before examination with a $100 \mathrm{CX}$ JEOL microscope.

Bacteria were seen colonizing the inner periostracal secretion (Figure $1 \mathrm{~A}, \mathrm{~B}$ ) in all of the specimens examined. Most of the bacteria observed were oval to rod-shaped and measured $3.9 \pm 1.2 \mu \mathrm{m}$ in length (mean $\pm \mathrm{SD}, \mathrm{N}=35$ ). In histological sections, the bacteria were clearly observed to contain refractile spherules (Figure 1B) similar to those seen in the endocellular gill symbionts (Figure 1C). These spherules are particularly evident in the negative TEM staining micrographs (Figure 1A). The bacteria were particularly abundant in the vicinity of the anterior and posterior inhalant syphons.

Rod-shaped and coccoid bacteria were observed within the bacteriocyte cells of the gill. The symbionts measured $3.6 \pm 1.2 \mu \mathrm{m}$ in length (mean $\pm \mathrm{SD}, \mathrm{N}=40$ ). They are characterized by the presence of translucent spherical vacuoles typical of sulphur inclusions in sulphur-oxidizing bacteria (Figure 1C). Bacteria morphologically identical to those found within the bacteriocytes, in terms of both their general appearance and size, were also observed both free within the lumen of the bacteriocyte channels (Figure 1C) and in close association with the ctenidial filament and transition zone of the gill filaments (Figure 1D).

As in all other symbiotic associations, $L$. lucinalis must maintain the animal-bacteria partnership over successive host generations (Smith \& Douglas, 1987). Recent studies on lucinids seem to indicate that transmission in these organisms is environmental (postspawning), transmitted to successive generations through free-living forms (Gros et al., 1996, 1998). These last 


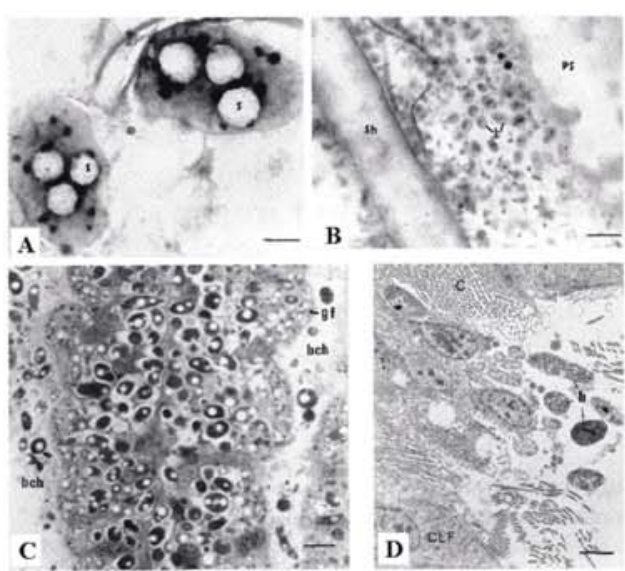

Figure 1. (A) Negative TEM staining of putative sulphur-oxidizing bacteria scraped off the imner periostracal secretion of Luripes lucinalis; B) transversal histology section of the periostracal secretion and shell showing extensive colonization by bacteria in which refractile spherules can be observed; (C) semi-thin section of the bacteriocyte region of the gill showing a gill filament. Note the numerous densely staining bacteria. The electron-lucent spheres within the bacterial cells indicate the location of sulphur spherules. On both sides of the gill filament can be seen a bacteriocyte channel that contains free bacterial eells; ( D TEM micrograph of bacteria free within the palial cavity in close association with the ctenidial filament zone and the transition zone of the gill filaments, b, bacteria beh, bacteriocyte channel; C, eilias

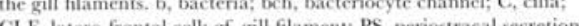
s, sulphur inclusion; Sh, shell. Scale bars: A, $1 \mu \mathrm{m} ; \mathrm{B}, 10 \mu \mathrm{m} ; \mathrm{C}, 7 \mu \mathrm{m}$; D, sulphur.

authors were able to experimentally colonize aposymbiotic juveniles of Codakia orbicularis with the free-living symbiont form through the addition of unsterilized sand collected from the bivalve's natural habitat. As pointed out by these last authors, such a transmission, if it is to be specific, implies some form of recognition mechanism between the host and the bivalve (for example: membrane receptor proteins). It is possible that the putative sulphur-oxidizing bacteria colonizing the periostracal secretion in lucinids may play a role in this type of transmission mechanism. Indecd, the bacteria observed colonizing the periostracal secretion are very similar, in terms of their general appearance and size, to those found colonizing the gill bacteriocytes. Also, the inner periostracal secretion represents a large surface area, even in juveniles, that would be readily colonized by environmental bacteria. The location of the host organisms within the sediment (presence of both reduced sulphides and oxygen via the inhalant syphon) would theoretically favour the colonization of sulphur-oxidizing bacteria. This seed population of periostracal secretion colonizers could thus play a role in the initial transmission of bacteria to the bacteriocytes, particularly since bacteria are abundant within the bacteriocyte channels and also appear numerous within the pallial cavity. Recently, intracellular methanotrophic bacteria were found outside the gill in hydrocarbon seep mussel juveniles, in mantle and foot epithelial tissues previously believed to be symbiont-free. These extra-gill symbionts and their host cells are morphologically similar to their gill counterparts (Streams et al., 1997). It was similarly hypothesized that the mantle epithelial bacteriocytes could mediate gill colonization by the bacteria during larval development. Alternatively, these periostracal secretion colonizers could represent a means of transmission to the oocytes as these exit the bivalve through the exhalant syphon.

Loripes lucinalis possesses a dense population of putatively sulphur-oxidizing bacteria colonizing its periostracal secretion. These bacteria may play a role in the postspawning transmission of bacteria. Research involving oocytes, juveniles and $16 \mathrm{~S}$ rRNA analysis is required to further elucidate the possible role of these periostracal secretion colonizers.

\section{REFERENCES}

Diouris, M., Moraga, D., Le Pennec, M. Herry, A. \& Donval, A., 1988. Chimioautotrophic et nutrition chez les Lucinacea, bivalves littoraux de milieux réducteurs. I. Activités enzy. matiques des bactéries chimioautotrophes associées aux branchies. Haliotis, Paris, 18, 195- 205.

Distel, D.L. \& Felbeck, H., 1987, Endosymbiosis in the lucinid clams Lucinoma acquizonata, Lucinoma annulata and Lucind floridana: a reexamination of the functional morphology of the gills as bacteria-bearing organs. Marine Biology, 96, 79-86,

Frenkiel, L. \& Mouza, M., 1995. Gill ultrastructure and symbiotic bacteria in Codakia orbicularis (Bivalvia, Lucinidae). Zoomorphology, 115, 51-61.

Gros, O., Darrasse, A., Durand, P., Frenkicl, L. \& Mouza, M. 1996. Environmental transmission of a sulfur-oxidizing bacterial gill endosymbiont in the tropical lucinid bivalve Codakia orbicularis. Applied Environmental Microbiology, 26, 2324 2330.

Gros, O., De Wulf-Durand, P., Frenkiel, L. \& Mouza, M., 1998. Putative environmental transmission of sulfur-oxidizing bacterial symbionts in tropical lucinid bivalves inhabiting various environments. FEMS Microbiological Letters, 140, 193 198.

Herry, A. Diouris, M. \& Le Pennec, M., 1989. Chemoautotrophic symbionts and translocation of fixed carbon from bacteria to host tissues in the littoral bivalve Loripes lucinalis (Lucinidae). Marine Biolog), 101, 305-312.

Johnson, M.A., Diouris, M. \& Le Pennec, M., 1994. Endosymbiotic bacterial contribution in the carbon nutrition of Loripes fucinalis (Mollusca: Bivalvia), Symbiosis, 17, 1-13.

Johnson, M.A. \& Fernandez, C., 2001. Bacterial symbiosis in Loripes lucinalis (Mollusca: Bivalvia) with comments on reproductive strategy. Journal of the Marine Biological Association of the United Kingdom, 81, 1-7.

Le Pennec, M. \& Beninger, P.G., 2000. Reproductive characteristics and strategies of reducing-system bivalves. Comparative Biochemistry and Physiology, 126A, 1-16.

Smith, D.C. \& Douglas, A.E., 1987. The biology of symbiosis London: Edward Arnold.

Streams, M.E., Fisher, C.R. \& Fiala-Médioni, A., 1997. Methanotrophic symbiont location and fate of carbon incorporated from methane in a hydrocarbon seep mussel. Marine Biology, 129, 465-476.

Submitted 29 January 2001. Accopted II Aprit 2001 